This is an electronic reprint of the original article. This reprint may differ from the original in pagination and typographic detail.

Author(s): Honkasilta, Juho; Vehkakoski, Tanja; Vehmas, Simo

Title: $\quad$ Power struggle, submission and partnership: Agency constructions of mothers of children with ADHD diagnosis in their narrated school involvement

Year: $\quad 2015$

Version:

Please cite the original version:

Honkasilta, J., Vehkakoski, T., \& Vehmas, S. (2015). Power struggle, submission and partnership: Agency constructions of mothers of children with ADHD diagnosis in their narrated school involvement. Scandinavian Journal of Educational Research, 59(6), 674-690. https://doi.org/10.1080/00313831.2014.965794

All material supplied via JYX is protected by copyright and other intellectual property rights, and duplication or sale of all or part of any of the repository collections is not permitted, except that material may be duplicated by you for your research use or educational purposes in electronic or print form. You must obtain permission for any other use. Electronic or print copies may not be offered, whether for sale or otherwise to anyone who is not an authorised user. 


\section{Power struggle, submission and partnership - agency constructions of mothers of children with ADHD}

\section{diagnosis in their narrated school involvement}

Honkasilta, Juho ${ }^{\mathrm{a}}$, Vehkakoski, Tanja ${ }^{\mathrm{a}} \&$ Vehmas, Simo ${ }^{\mathrm{b}}$

${ }^{\mathrm{a}}$ Department of Education, Special Education, University of Jyväskylä, Jyväskylä, Finland; ${ }^{\mathrm{b}}$ Department of Social Research, University of Helsinki, Helsinki, Finland

Juho Honkasilta, M.Ed., PhD. candidate

University of Jyvaskyla*), Department of Education, Special Education

P.O.Box 35, FI-40014 University of Jyvaskyla, Finland

Email: juho.honkasilta@jyu.fi

Phone: +358408053634

*) for technical/conversional reasons letter ä is replaced with letter a

Tanja Vehkakoski, PhD., University teacher, Adjunct professor/Docent

University of Jyvaskyla, Department of Education, Special Education

P.O.Box 35, FI-40014 University of Jyvaskyla, Finland

Email: tanja.vehkakoski@jyu.fi

Phone: +358408053627

Simo Vehmas, PhD., Professor of Disability Studies

University of Helsinki, Department of Social Research

P.O.Box 16, FI-00014 University of Helsinki, Finland

Email: simo.vehmas@helsinki.fi

Phone: +358504160481

Corresponding author:

Juho Honkasilta 


\title{
Power struggle, submission and partnership - agency constructions of mothers of children with ADHD diagnosis in their narrated school involvement
}

\begin{abstract}
The contemporary education paradigm highlights the interdependency of home and school expertise, yet the school institution possesses and exercises power over parental involvement. This discourse analysis study examines the narrated agentive possibilities of 18 Finnish mothers of children diagnosed with ADHD to influence and be involved in their child's schooling. The results show that the mothers exhibited a strong, yet forced, will to participate, mainly due to lack of confidence in teachers' knowledge of ADHD and ability to treat their children as other than 'disorderly'. Additionally, our analysis reveals a gap between the mothers' narrated potential agency as a 'good mother' fighting for her child's well-being and their actual capability to be involved as intended due to unequal institutional power relations between home and school. This study sheds light on the shared educational responsibilities of the home and school, and the role the ADHD label plays in educational social practices.
\end{abstract}

Keywords: maternal agency, home-school cooperation, ADHD, discourse analysis 


\section{Introduction}

Meeting the criteria for being a 'good', 'well-behaved' pupil in contemporary schools is challenging, as is identifying individuals that deviate from these normative criteria and recognizing their 'remedial needs'. The United Nations General Assembly (1993) has recognized inclusive education as a guiding principle of compulsory schooling. In addition, the current education policy paradigm highlights the interdependency of home and school expertise and teachers' key role in enabling parents' active involvement in their children's schooling (e.g., Patrikakou \& Weissberg, 2000; Pena, 2000), which has been reported to improve, for instance, children's confidence, self-regulation and academic motivation in school (e.g. Hoover-Dempsey et al., 2001; Gonzales-DeHass, Willems \& Holbein, 2005). Paradoxically, educational social practice is claimed to be strongly committed to medical, rather than inclusive discourse (Lloyd, 2006), co-establishing the medical model of disability, i.e. institutional commitment to explain a child's undesirable behaviour through psycho-medical explanations while disregarding its contextual and social origins (e.g., Gresham, 2002; Thomas \& Loxley, 2007, see also Hjörne \& Säljö, 2004; McHoul \& Rapley, 2005). Thus, instead of home and school taking joint educational responsibility for children with manifest difficulties in selfregulation and in regulating attention, activity and impulsivity 'appropriately', the medical model labels the behaviour as a neuropsychological dysfunction called attention deficit hyperactivity disorder (ADHD). This may lead to segregative professionalization of educational responsibility in order to measure up to the biomedical expectations that the label implies (e.g., Lloyd, 2006; Thomas \& Loxley, 2007, p. 27).

Although children falling under the globally steadily increasing diagnosis of ADHD have been shown to have academic and social difficulties (e.g., Ohlmeier 2008; Scholtens, Rydell \& Yang-Wallentin, 2013), these possible adverse trajectories cannot be explained solely in terms of inadequate cognitive processes. Rather, they represent the gap between social expectations and the individual's current capability to function accordingly. However, the commitment to the neurobiological explanation of their child's problems often holds true for mothers (e.g., Harborne, Wolpert \& Clare, 2004; Frigerio, Montali \& Fine, 2013). For instance, perceiving their child as being misjudged and not adequately pedagogically or socio-emotionally supported at school can lead mothers to actively seek the ADHD diagnosis for their child (Kos, Richdale \& 
Hay, 2006; Carpenter \& Austin, 2008) in order to get their child's remedial needs recognized, and learning development and self-image supported (Emerald \& Carpenter, 2010).

According to earlier research, parents are likely to be more knowledgeable about ADHD than teachers (West et al., 2005). They are also concerned about their child being at high risk for school failure (LaFever, Villers \& Morrow, 2002). Studies investigating teachers' perceptions of pupils with the diagnosis or manifest symptoms of the disorder have revealed negative stance towards ADHD and individuals with the diagnosis, feelings of incompetence, as well as the tendency to label a child as disorderly and/or to stigmatize them (Greene, Beszterczey, Katzenstein, Park \& Goring, 2002; Ohan, Cormier, Hepp, Visser \& Strain, 2008; Ohan, Visser, Strain \& Allen, 2011). Thus, clearly, if teachers view pupils with the diagnosis primarily as a nuisance, parents are likely to question the teachers' knowledge of their child's behavioural traits and also the appropriateness of the teachers' emotional response to them. Furthermore, as the child becomes labelled as maladjusted and behaviourally disturbed, especially mothers become also easily prone to blame (e.g., Singh, 2002; 2004; Austin \& Carpenter, 2008).

Nowadays, in western society parent and teacher expertise are generally considered interdependent. The prerequisites of successful collaboration are widely known and reported; they include factors such as open reciprocal communication and other facets of trust, teachers' know-how and positive attitude towards pupils' remedial needs (e.g., Angell, Stoner \& Shelden, 2009), and, parents' sense of being a legitimate party in their children's schooling (e.g., Pena, 2000; Pelletier \& Brent, 2002). Nonetheless, inequality and disparity of power and authority in parent-teacher collaboration prevails widely (e.g., Hodge \& Runswick-Cole, 2008, Frigerio et al., 2013). Teachers possess the legitimate power over either welcoming or marginalizing parents' contribution (Carpenter \& Austin 2007; O’Connor, 2008), and parents of children with ADHD have reported feeling less welcomed by their children's school than parents whose children did not have ADHD (Rogers et al., 2009).

\section{Purpose of this study}


In order to understand parents' involvement in collaboration with school, this article examines the agency positioning of mothers of children diagnosed with ADHD in relation to constructed possibilities/limitations in their narrations about influencing and being involved in the schooling of their children. The concept of agency is much contested between and within different disciplines (see Ahearn, 2001; Arnold \& Clarke, 2013). Our conceptualization of agency derives from the social constructionist approach, and the analysis of mothers' agency is based on the tradition of linguistic discourse analysis that highlights the action orientation and functionality of language (e.g., Wetherell, 2001). Agency "refers to the socioculturally mediated capacity to act" (Ahearn, 2001, p. 112) performed intentionally within socioculturally constructed possibilities and constraints (e.g., Fairclough, 2004). These margins of agency construction are constituted by the discourse $(\mathrm{s})^{1}$, and intentionality is understood as active social meaning making (Harré \& van Langenhove, 1999) through which mothers contextually display themselves as agents of certain kinds (e.g., victim) in relation to certain discourses (e.g., normative discourse of 'good' parenting).

Karp (1986) distinguishes between an actor and agent, the former referring to a person performing rulegoverned or -oriented actions, and thus, reproducing social world (discourse), whereas the latter refers to a person's ability to engage in the exercise of power in order to contribute to and co-construct the social world. Emanating from the positioning theory, agency is examined in this study through subject positioning with a reference to discursively constructed social identities that entail a "cluster of rights and duties to perform certain actions" (Harré \& Moghaddam 2003, 6). The subject is positioned to act in accordance with the cultural norms that ultimately legitimate her position, for example, as a good mother or educational expert (Tirado \& Gálvez, 2007; Harré, Moghaddam, Pilkerton, Rothbart \& Sabat, 2009). So, although a mother legitimately claims the position of aforementioned expertise concerning her child's disorder, her capability to act accordingly as intended in the context of home-school collaboration might be produced much more limited and ultimately determined in social practise between her and school personnel. Thus the question is,

\footnotetext{
${ }^{1}$ We conceptualize discourse as a socioculturally constructed and shared distinctive representation of social, political, cultural and institutional reality (e.g. institutional power relations) based on specific domains of norms, beliefs, ideals, values, and knowledge to which agents have limited access (see Foucault, 1972; Fairclough, 1992; van Dijk, 1996; Gee, 2004).
} 
what kind of agencies mothers have access to within the very discursive context (e.g. active-passive, subordinate-authoritative).

The first focus of our study is on the ways in which mothers of children with ADHD diagnosis construct their agency with respect to their children's schooling in terms of different subject positions. Additionally, as the mothers' agency constructions are school-oriented, they simultaneously create certain images about the school institution and its exercise of power; this forms our second research focus. The research questions are thus interwoven, as the images of school formed by the mothers restrictively impact the way in which they position themselves in relation to the school and vice versa.

\section{Method}

Originally, twenty-five Finnish families (25 mothers and 7 fathers) of children diagnosed with ADHD participated in the research. Participant recruitment was carried out with the help of the Finnish ADHD association, which provides support and information for persons with symptoms of ADHD and for their social networks. Families voluntarily contacted us only if they were willing to participate. Due to fathers' low participation, this article focuses solely on the agency constructions of eighteen mothers who were interviewed without their spouses. This decision reflects earlier research findings indicating that mothers are dominantly in contact with educational professionals (e.g., David, 1998) and more engaged in their ADHD diagnosed child's schooling than fathers are (Rogers et al., 2009). Apart from the common ADHD association background, the mothers formed a heterogenic group in terms of age, educational and work background, activeness in the association, relationship status, diagnosis, health, and diagnosis and comorbidity of the child. In this maximum variation sampling, shared emerging patterns are of interest as they capture the core experiences of the one thing common to all, i.e. a child diagnosed with ADHD (Patton, 1990).

The interviews were based on a loose, thematic interview outline concerning mothers' conceptions of children's comprehensive schooling and home-school interaction. This enabled the mothers to engage in free intuitive talk around the themes. The mothers' storylines were dominantly constructed around maternal 
responsibilities for the well-being of their children and their expertise in ADHD, which had to be negotiated with the school. The mothers' narrated possibilities for agentic positioning thus formed the focus of the present research. Interviews were conducted in a location chosen by the participants (e.g. their homes, university) and lasted on average one and a half hours.

The data was processed on a cross-case basis using critical discourse analysis (CDA). In CDA the focus is on the relationship between language and society and on how power relations are discursively constituted (e.g., Fairclough \& Wodak, 1997). The central premise of CDA is to analyse how language form (morphemes, word choices, phrases, or other syntactic structures) and function (meaning or the communicative purpose a form carries out) correlate with social practices (e.g., school involvement) (Gee, 2004). Our naming and defining of subject positions was based primarily on verb expressions by means of which the mothers referred to themselves as subjects in the process of enhancing their children's school well-being. The analysis of verb expressions enabled a tentative understanding of the nature of the mothers' agency positioning. In addition, detailed examination of the form of the utterances within the context (ranging from a sentence to a whole turn) in which they were used was needed in order to analyse the relation between the functions that the utterances served and the agentic possibilities they revealed.

The trustworthiness of the study can be assessed from various aspects. Controllability, non-judgementality, and diminishing the possibility of biased interpretations were striven for by systematically coding both the grammatical and contextual features of the utterances (Wetherell, 2001). Collaboration between researchers during the analysis process enabled cross-reading and constant comparison of the data analysis within the methodological and theoretical frames of CDA, and thus strengthened the conformability of the analysis. Assessment of credibility of the research is made possible for the reader in the Results section by means of authentic data examples followed by detailed analysis and reasoning. The transferability can also be partly justified by our methodological approach, in which we consider the mothers' agency to be located at a sociocultural rather than solely individual level and thus, in which the mothers' positioning of agency is seen as a representation of socioculturally constructed, shared understanding of institutional power relations. 
The analysis was conducted in Finnish and the data excerpts were translated into English with the assistance of a language consultant with an emphasis on idiomatic translation and replicating the original verbatim records as exactly as possible. All names used in the article are pseudonyms. The following transcription symbols are used: (.) micro-pause; (1.0) pause measured in seconds; (--) two or more words missing; [ simultaneous and overlapping speech; $[\mathrm{JH}: \mathrm{Ok}]$ overlapping short utterances of participants inserted in ongoing talk; ((ADHD)) author's clarification; “ ” reported speech.

\section{Results}

The mothers' agency positioning seems to take different forms, which we have categorized as forced strong agency (power struggle), volitional strong agency (cooperation) and weak agency (submission). In positioning their agency, the mothers also embody various conventions of power in relation to their own position and the policies and practices of the school. The school institution is constructed as a legitimate entity with considerable power over the mothers' agency formations; teachers specifically play a significant role in the construction of the mothers' versatile agency positions because, ultimately, their agency is narrated to be produced in interaction with the teachers. In terms of power, Figure 1 sums up the agency constructions of the mothers in relation to being ignored or accepted by the school.

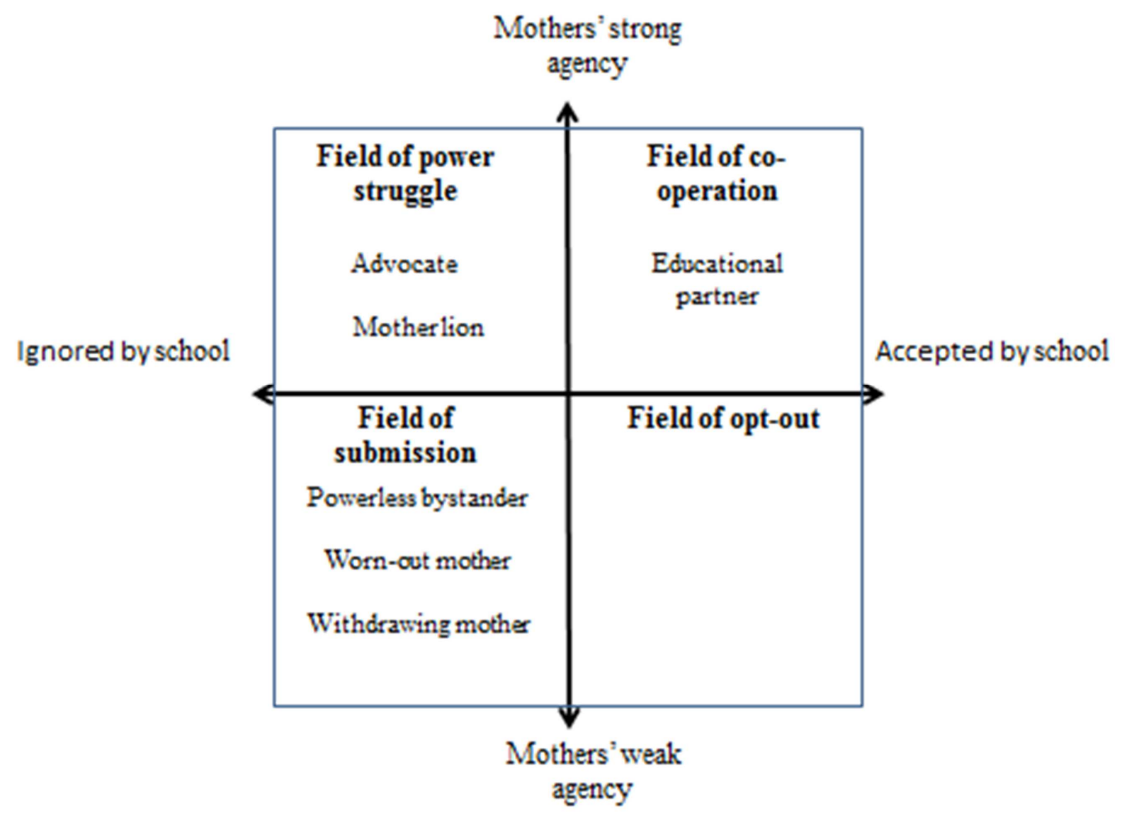


Figure 1. The fields of power generated in relation to the mothers' agency constructions and the schools' exercise of power.

When expressing forced strong agency, the mothers position themselves into two subject positions with different emphases: advocate and mother lion. Conversely, when manifesting weak agency the mothers become positioned as powerless bystander, worn-out mother, or withdrawing mother. The first five positions, representing the most dominant and prevalent framework for embodying agency, stem from characterizing primary school as an unfavourable social environment for a child to grow up in due to its segregative practices. These positions thus highlight the mothers' concern about their children's well-being at school as being the main incentive for school involvement. In contrast, volitional strong agency stems from this concern being taken into account by teachers, thus positioning the mother as an educational partner.

Empirical evidence of the field of opt-out in figure 1, i.e., possessing weak agency despite school's welcoming stance, was not provided in our data. This type of agency construction would potentially mean that mothers do not share the ideal of interdependency regarding educational duty and expertise. Rather, they would reproduce the juxtaposition of home and school and, thus, simply transfer responsibility of their children's education to authorities who are believed to possess superior educational expertise. The absence of this agency construction could be explained by the fact that the mothers were summoned to talk about their school-related experiences with an unfamiliar researcher; their agency positions may have been directed by the research agenda, as well as the sociocultural norms concerning good parenting.

\section{Forced strong agency}

\section{Advocate - aiming for partnership with the school}

When positioning themselves as an advocate, the mothers emphasize their active attempts to participate in, contribute to and, above all, improve their child's everyday school circumstances. This positioning involves the use of neutral verbs in the first person singular that highlight the mother's active and constructive role in their child's school life (e.g. "I got the ((special education class)) place sorted out (--) on my own" (N13), "I 
gave ((the teacher information)) about the ADHD" (N14). Despite this way of referring to themselves as peaceful agents, the mothers nevertheless construct an explicitly negative image of the school, as demonstrated in the following excerpt in which one mother (Olivia) describes a situation where she had to collect her child from school in the middle of the day. Previously, she had stated that medication had been considered by the school as the only means of support for her child.

\section{Extract 1:}

1 Olivia:

It was when he had some sort of really bad temper fit and ((physically)) had a go at one of the

Olivia: teachers (1.0) [JH: Aha] (--) that was after that female teacher's lesson too (1.0) [JH: Ok] it was a struggle with her lesson (.) and after that he just snapped so (3.0) and and (1.0) then I spoke briefly with the principal about whether he could be excused ((from the lessons)) 'cause he's obviously bothered by that teacher's lessons (1.0) [JH: Aha] he just started going on at me on the phone that "yeah but he's got medication and he had medication before he came to our school" (--)

JH: $\quad$ Right, so (.) it was stated that there is medication [that it (.) should "yes well he has to be in the teacher's lessons" so (3.0) that was one time when I'd gone and taken him out of school again so like ((the principal said)) "yes he has to be able to attend Heidi's lessons" [JH: Right] (1.0) so (.) it's pretty bloody obvious you're getting nowhere (3.0) [JH: Right, so] for the principal it was totally ((all about)) the medication, at least he was ((like that)) to me as soon as I said on the phone about it that "yeah 'cause he's got medication" (N3, Olivia)

Criticism of the school clearly emerges in the way Olivia describes that her child "had some sort of really bad temper fit" due to being worn out by a certain teacher. Criticism is also revealed in the way she describes the principal ignoring the contextual and social factors leading to her child's victimization, as if the child's inherent neurobiological deficit is manifested in his medication which automatically absolves the teacher from responsibility for the child's malaise: "he just started going on at me on the phone that 'yeah but he's 
got medication and he had medication before he came to our school'". In other words, the principal ambivalently considers the child as disordered, yet responds to him as disorderly by not providing any means of remedial education to him. This motivates Olivia to get more involved in her son's education, even though the principal disapproves her attempts and, thus, constrains her agency positioning. This becomes evident when the mother creates a contrast between the nature of her actions and those of the principal (I spoke - he just started going on at me) and where the use of the adverb 'just' strengthens the image of the principal ignoring Olivia's request. Yet Olivia's neutral references to her own actions ("I spoke", "I'd gone and taken him out of school again"), as well as the use of the modal verb "could' ("whether he could be excused"), indicating an action being possible if authorized by the school, cement the peaceful nature of her agency construction as she aims for alternative solutions without conflict. This agency positioning is twofold: as a mother the only viable action to take to protect her child was to get him away from the school, whereas as a partner in the home-school partnership this was the only action left open to her by the school.

In addition to describing through the use of neutral expressions how they fight their case at school, the mothers construct strong agency by highlighting how essential and crucial their attendance has been to their child's survival at school. The importance of the mothers' contributions is emphasized when they describe taking the initiative to gain knowledge about ADHD after their child's diagnosis, thus gaining strong agency and authority about the disorder. In this way, the mothers construct themselves as experts (e.g. "I've been the one that knows about it ((ADHD)) and has told others about it too", N8), whereas the school institution is shown as passive with comparatively little knowledge of ADHD and a lack of ways to adapt teaching procedures to meet the educational needs of pupils. In addition, also the school's failure to provide its pupils with psycho-social support is highlighted in the mothers' agency construction (e.g. "((the child)) gets branded if I don't sort of go and ask ((the teacher)) to really get to the bottom of things ((the incident))", N6). In this sense, the mothers posit that if they had not stepped in, their children would have been stigmatized as bullies or deviant by both their peers and teachers.

In sum, positioning of advocacy forms the basis of mothers' attempts to get involved in their children's schooling. This agency construction is premised on home-school collaboration and the mothers' knowledge and understanding of ADHD, which form a potential interwoven solution for the children's difficulties at 
school. ADHD diagnosis is seen to explain children's experiences at school (e.g., being perceived as nuisance, being bullied, being understood and supported), justify need for remedial education, promote teachers' constructive stance towards them, and legitimate mothers' expertise of the condition and thus their contribution to their children's schooling. The rest of the following agentive positions, however, are adopted solely in relation to schools respond to mothers' attempts.

\section{Mother lion - struggling with agency and child's well-being at school}

The mother lion subject position arises in the context in which the mothers describe schools as neglecting both educational partnership and pupils' well-being. Like the advocate subject position, the basis of this position is formed by the mothers' constant efforts to collaborate with the school to ensure adequate support for their children. The mothers do not, however, describe their agency as peaceful through neutral expressions, but rather as more aggressive and demanding after being ignored or resisted by the school. This is evidenced by the use of struggle- and demand-related verbs (e.g. "the special education teacher (--) who I really clashed with ((after being ignored despite her child had the decision of special education placement))", $\mathrm{N} 15$ ), in expressions highlighting the number of attempts ("we told the principal like loads of times that we don't accept this kind of thing ((locking the child into a booth as a punishment))", N17), and expressions emphasizing the mothers' vain attempts to ensure educational support for their children (e.g. "and no matter how much I tried explaining to them ((about her son's comorbid perceptual disorder explaining his delays))", N8). In the following Extract 2, a mother (Andrea) describes a breakdown in communication with school staff due to setbacks in the course of trying to achieve a legitimate position in the educational partnership in order to make her child understood and pedagogically supported at school.

\section{Extract 2:}

What I've noticed here about (--) these practices in different towns is that (.) with many of them just the diagnosis alone sort of like (1.0) the (.) school puts it straight into the IEP ((individual educational plan)) so they immediately change the (.) teaching (2.0) but what I sort of really don't understand is that is there like (.) there has to be sort of something else 
here like something totally personal of course I (.) sort of like (.) there has to be something more to this (.) 'cause there's clearly no sort of (.) discussion here about what's best for the child (1.) of course I've also sort of learned over the years to like (.) hit back if needed when I hear those comments about the child not having a father and oh how terrible ((and so on)) 'cause (.) I'm also (1.0), think about it now hey a single mum and (.) homemaker and everything right (2.0) so like (2.0) these (.) these my kind of (.) comments like (.) I know that they're sort of really (.) negative I have had from the school some I have ((experienced)) some good things too (1.0) but if this sort of I'm like so frustrated for the boy that I like fight year after year that (.) I'd just get him some sort of education (.) so he wouldn't have to feel so bloody stupid each day (3.0) so it's not all like that we're not always just arguing with the head we do sometimes have some totally (1.0) rational moments too. (N10, Andrea)

In Extract 2, Andrea constructs her son's school as negligent due to disregard his special education needs. She thereby casts a shadow over the school personnel's motives (saying that the child's welfare is being ignored due to personal reasons) and sensitivity; her status as the child's rightful, passionate advocate is questioned because she is seen to be insufficient (her being a single mother). This positioning suggests that Andrea is automatically suspect, lacking proper expertise. The juxtaposition of Andrea and the school is described as an ongoing, frustrating struggle ("I like fight year after year") where the ADHD diagnosis has become a crucial factor in her struggles for getting better education for her son. Andrea, however, has refused to be marginalized by the school: "of course I've also sort of learned over the years to like (.) hit back". She thus fortifies her strong agency and legitimizes the cause she is, reactively, forced to fight for.

The bona fide concession in lines 10-11 ("I know that they're ((her comments)) sort of really (.) negative"), as well as denying constant struggle ("it's not all like that we're not always just arguing with the head we do sometimes have some totally (1.0) rational moments too") serve, however, the rhetoric function of being perceived by the interviewer as capable of collaboration (see Antaki \& Wetherell, 1999). This can be understood as an attempt to avoid the possibility of being seen as playing the role of a 'difficult mother' but instead, as highlighted throughout the storyline, as performing the only possible form of agency as a 'good mother' protecting her child from feeling "so bloody stupid each day" enabled by the school. The mitigation 
of her motives to 'fight' through the adverb 'just' ("I like fight year after year that (.) I'd just get him some sort of education") fortifies her intentions as being good and as deriving from her son's ill-being at school.

In extreme cases, the mothers reported breaking communication with the school after feeling that their autonomy had been questioned (e.g. "it became such an obvious power struggle about who's right that I broke off communication with the school", N10). The mothers also emphasize the unreasonableness of the school's actions by defending their own aims as reasonable. This is seen in such remarks as "I don't even ask for a personal assistant" (N11), in which minimization is expressed through the word 'even', referring to the mother's legitimate option to ask for a lot more (from which she refrains).

To conclude, forced strong agency stems from perceived negligent social practices at school that contradict mothers' expectations concerning the school's educational expertise. In mothers' view, their children are almost exclusively seen disorderly at school, which forces the mothers to intervene and adopt an expert position concerning ADHD. Strong affective expressions (e.g., "it's pretty bloody obvious you're getting nowhere", N3) are related to school's failure to accommodate their children's individual, remedial needs. Conversely, mothers' own collaborative pursuits are narratively illustrated as constructive, conciliatory, and done exclusively for the sake of their children. The self is thus positioned as a strong, responsible agent in contrast to negative construction of the school's modus operandi.

\section{Volitional strong agency}

\section{Educational partner - cooperating with teachers}

When positioning of educational partners is enabled, the mothers express that they actively participate in their children's school lives together in one accord with the teachers. This is assured, and thus their own actions as mothers are sanctioned by referring to positive feedback received from authorities and teachers, (e.g. "I got from so many teachers there ((feedback)) that it's great that there are mothers like that who sort of look after their children's interests so well and that you can be proud of yourself", N5) and by expressing satisfaction with teachers (e.g. "I'm sure his own teacher understands ((the importance of adapted teaching 
methods for "ADHD-kid")), we get on with him really well”, N3). The mothers also emphasize functional communication between themselves and the teachers, as seen in Extract 3 below.

\section{Extract 3:}

I know the teacher would definitely phone me at home if something came up and not always just only about negative things either [JH: Right] they contact me at home by like now and then just sending a message that the day's gone really well and that (.) there've been no problems (.) and then I've been able to phone the teacher if something comes up at home and [JH: Right] (.) keep them updated and (.) they always get involved in everything at the school and if there's been any cases of bullying too so like (.) if Alex has been involved or been bullied himself or (.) if he's been bullying I've always been able to like talk about any issues and (.) sort them out and [JH: Yeah] (1.0) just generally this school's been really fantastic that they (.) get involved in like absolutely everything so (1.0) nobody gets away with bullying anybody there. (N9, Mariela)

In Extract 3, Mariela positions her agency as an educational partner by emphasizing reciprocal communication between her and her child's teacher ("I know the teacher would definitely phone me at home"; "I've been able to phone the teacher if something comes up at home and (.) keep them updated"; "I've always been able to like talk about any issues and (.) sort them out"). Communication is constructed as absolutely open and based on trust by means of the extreme expressions "definitely" and "always" (lines 1 \& 7) including circumstances where Mariela's child is told to behave badly (lines 6-7). Simultaneously, she constructs herself as a responsible, unbiased educator capable of dealing with her child's possible bad behaviour. However, Mariela makes clear with the use of expression 'be able to' ("I've been able to phone the teacher"; "I've always been able to like talk about any issues") that it is up to the teacher to decide whether she will be included to the teacher-parent collaboration; the teacher is positioned to be the one that enables Mariela's strong volitional agency. 


\section{Weak agency}

\section{Powerless bystander - submitting to being ignored}

In this subject position, the mothers strongly co-experience their children's unfavourable school circumstances, but unlike the previous subject positions, they construct their children's everyday school lives as something they have no power over. The mothers construct an image in which they are (practically) forced to accept roles given to them by the school by emphasizing their powerlessness to create any options other than acting according to the school's demands (e.g. "so then I ended up having to pick him up ((the child from school))", N3). In addition, weak agency is constructed by the mothers' expressed uncertainty and concern about their children's future (e.g. "where are we going to end up again next autumn", N1). In the following Extract 4, a mother (Damarys) cites being marginalized by the school through lack of knowledge of whether adapted teaching methods written in her child's individual educational plan (IEP) are being used. Previously in the interview she had mentioned her dissatisfaction with the teacher's suggestion of carrying out the annual meeting obliged by the IEP via email, not face to face, after it was Damarys herself who had reminded the teacher over the matter.

\section{Extract 4:}

Well there ((in the IEP)) are (.) written different (1.0) well at first there were also like quite a lot of goals on the sort of social side (2.0) so trying to also support that side but (.) so yeah it's like (.) all those beautiful words there on paper but as parents we don't know anything at all about what (.) what's been done about them or (.) if anything's been done (1.0) then in the spring we just hear that this is how it went. (N4, Damarys)

Weak, submissive agency position in relation to school becomes evident in Damary's negative or static way of using verbs ("we don't know anything"; "in the spring we just hear"): parents are positioned as passive recipients who await the school's invitation to participate in the development of their children's education. Despite her narrated earlier attempts to be involved, Damarys's possible agency in terms of participation becomes defined within the frames of communication between home and school: "as parents we don't know anything at all about what (.) what's been done about them". The emphasis on being left outside is made by 
means of an extreme expression "anything at all" along with uncertainty about the teacher's commitment to the IEP: "if anything's been done". Thus, the teacher's way of action leads Damarys to submit to her role as a powerless bystander, who can only 'drift with the tide' with no chance of influencing the course directed by the school.

\section{Worn-out mother-fatigue due to child's manifest ADHD symptoms within the school context}

The worn-out mother subject position is similar to the powerless bystander position in terms of constructing powerlessness to influence their children's school circumstances. However, the focus of this subject position is exclusively on the mothers' emphasis on being worn-out from coping with their children's ADHD symptoms at home or from struggling with the school, as well as on their attempts to balance their own coping with their children's school well-being. This is put into words by expressing the laboriousness of contributing to the child's schooling at home due to their symptoms of inattention (e.g. "so like I can't make sure he has like every ((homework)) assignment done 'cause it just takes such an endless amount of time", N12) or by expressing fatigue and self-blame, as shown in Extract 5 below. Previously, the mother (Andrea) had reported that, despite her active attempts, her son does not receive any form of adapted support at school because his problems of inattention in school performance are not outwardly visible, i.e., he does not "jump off the window sills and everywhere, and make a racket and shout" nor have "speech problems or any like really obvious birth disorder or anything" (Andrea).

\section{Extract 5:}

It kind of annoys me that I'm so pathetic that I don't like (.) have the strength to sort of (.) fight for it ((support in school)) but (2.0) I've already been thinking that (.) when I get the sixth grade (.) get him through that (1.0) then sort of fingers crossed in lower secondary he'll get the kind of like (1.0) 'cause he's already got a slightly bigger risk of running into problems anyway now so (.) like in lower secondary I'd get him the kind of teaching that he wouldn't 
Through the expressions of self-blame and self-reproach ("It kind of annoys me that I'm so pathetic that I don't like (.) have the strength to sort of (.) fight for it"), Andrea describes her fatigue as a consequence of failing to attain strong agency in his son's schooling. The biggest threat ensuing her fatigue is related to her son's ADHD and the possible adverse life trajectories related to it; she fears that she will not able to prevent her child from "totally fall[ing] by the wayside in the world" due to his "slightly bigger risk of running into problems anyway". It is noteworthy that Andrea's submissive agency is not explained in terms of her personal attributes nor is her concern about his son justified through the medical model of disability. Rather, they are seen to result from school's constraining practices (lines 5-8). She maintains hope of being able to champion her child's case in the future if given a chance: "I've already been thinking that (.) when I get the sixth grade (.) get him through that". However, uncertainty about future school's capability to support her child, and, powerlessness in the face of school institution is expressed by simply hoping for the best: "fingers crossed in lower secondary he'll get".

\section{Withdrawing mother - acknowledging limitations}

The withdrawing mother is by far the most unusual of all the subject positions present in this paper. Characteristic of this position is that the mothers construct their agency as rather passive with no explicitly expressed criticism of the school, although it is still constructed as an unfavourable environment for a child with ADHD symptoms.

\section{Extract 6:}

I somehow got the feeling that we're like a 'pain in the ass' (.) as parents because then (.) of 
like (.) area of responsibility I don't go and challenge that, but sort of like (.) it was (.) I felt

that there was hardly any understanding at all from that side. (N6, Justina) 
In Extract 6, the Justina differentiates between parents' and the teacher's expertise and positions herself as a misunderstood agent by the school ("I felt that there was hardly any understanding at all from that side"). She tones down the expressed criticism by empathizing her withdrawal from the juxtaposition of parents and teacher through the use of the coordinating conjunction 'but' ("but hadn't sort of seen what happens at school"), which differentiates the experienced realities of these educational institutions from each other. This is also emphasized through naturalness of her not intervening ("and of course we wouldn't understand that"). Home and school are constructed as separate entities with limited expertise within each other's domains and, thus, the teacher's institutional authority over parental agency positioning in school involvement remains unquestioned. In the interview interaction, such withdrawal opposes possible portrayal of self as 'difficult mother' and, rather, cements one as 'knowing her place'.

As a conclusion, narrated weak agency derives from school's denial of its responsibility for children's wellbeing. Also, school's perceived passiveness and consequential reliance on home's expertise in resolving ADHD-related issues are narrated as causing imbalance between mothers' own coping on the one hand, and advocating children's school well-being on the other. These circumstances lead to submission, as own potential and intended agency is overrun by school's practice. In terms of blame, our findings resonate with Singh's $(2002 ; 2004)$ work on ADHD and mothering in a culture of mother-blame. The culture of blame becomes enforced through positioning the child and the self as victims of school's negligent abuse of power which does not only disempower mothers' agency concerning educational expertise and partnership, but it may also have negative effects on her self-image as a mother.

\section{Discussion - distrust, disempowerment and 'the promise of ADHD'}

In this study, we examined the agency of mothers of ADHD-diagnosed children as discursive practice in terms of their narrated possibilities to influence and participate in their children's schooling. The study demonstrated that the mothers' narrations about teachers' passive and negligent practices were used as a basis for exhibiting strong agency in home-school collaboration. However, the agency was more imposed and forced than volitional; the mothers' lack of confidence in the teachers' knowledge of ADHD and, thus, 
ability to support their children's psychosocial well-being at school were constructed as the main reasons for their attempts to get strongly involved and fight for their child's well-being as a 'good mother'. Thus, on one hand, the mothers highlighted their strong will to participate in their child's schooling, but on the other hand they expressed a wish to give teachers stronger responsibility than they seemed willing to accept. Teachers were expected to possess a wide range of knowledge about ADHD in order to deliver objective information to parents and to meet the child's needs accordingly; simultaneously, the mothers also questioned the teachers' expertise concerning ADHD, which was constructed as inferior to that of the mothers. This ambivalence is similar to what Frigerio and colleagues (2013) conceptualize as "the blame game", referring to the (re)production and resistance of unequal power relations between the mental health professionals, teachers and parents in terms of negotiating the allocation of adequate means, rights, duties and obligations in 'treating ADHD'.

In addition of the ambivalences in the positioning of expertise between the home and school, another notion of ambivalence in our study concerned 'the promise of ADHD' that seemed to be an a priori knowledge domain from which the narrated storylines in the interviews derived. The label ADHD was expected to change the school's view of a 'disorderly' or 'normal' pupil to a 'disordered' (see Graham, 2007) - ADHDpupil - and thus provide understanding, approval, and pedagogical support for the child. Not only was a child's maladaptive behaviour or unrecognized remedial needs (see Emerald \& Carpenter, 2010) expected to be recognized along with the label, but also the mothers' concern about and expertise in their child and the disorder. This reproduction of the medical model might be an outcome of the society's normative social practices, leaving the mothers with no choice other than to medicalize human differences whilst their attempts to enhance inclusive understanding were disregarded. The fact that the mothers' advocacy was predominantly attached to medical discourse could also be considered a possible downfall of home-school collaboration, as it partly led to conflicts with teachers opposing their view (e.g., Harbourne et al., 2004). Ultimately, the child is a pawn on the board of recognition in this power game - and the one that is victimized.

The mothers' interviews also revealed that teachers were constructed as possessing power over the mothers' agency by either empowering the mother's volitional involvement in a partnership characterized by 
reciprocal trust and openness (see e.g., Soodak \& Erwin, 2000; Angell, Stoner \& Shelden, 2009), or by enabling only submissive, weak agency due to domineering exercise of power. In contrast to their negative construction of the school, the mothers opposed any possible portrayal of themselves as 'difficult mothers' highlighting thus their victimization by the school. Therefore, the recognition of the deep distrust the parents (of children diagnosed with ADHD) may have of the school due its everyday social practices that are perceived as reproducing inequality and disparity of power, and neglecting children's comprehensive wellbeing is necessary in order to create an open and trustful relationship. This is also of importance in order to enable and encourage parents' positioning in the partnership as agents (contribute to the exercise of power) instead of mere actors (reproduce the unequal power relations) (see Karp, 1986). The issue at hand is the constant negotiation of agency, expertise and power between mothers and teachers. This power struggle, as exposed in our analysis, should be considered as a constructive, yet fragile dialogue (rather than something that threatens one's agency) in which parties negotiate to work towards a common educational goal.

Since medical and normative discourses are deeply rooted in educational comprehension of variation between individuals' behaviour, the 'promise of ADHD' seems to remain salient and self-sustainable in everyday social practices. The diagnostic label per se cannot be considered fundamentally undesirable, yet if educational and pedagogical understanding of a child with difficulties in regulating attentiveness, impulsiveness, activeness and self-control 'adequately' is solely diagnosis driven and medicalized little room remains for critical constructive (re-)evaluation of fundamental educational values, such as ideas of man, learning, and power. Indeed, there are other equally important processes alongside learning in which children need to be jointly supported by adults both in and outside the school, such as the development of social skills and, not least, a 'healthy' self-image. The question thus raised is what are the differentiated and joint educational tasks between the home and school in these important issues.

Finally, some methodological observations regarding the limitations of this study are in order. One striking feature of our research results is the immoderately negative characterisation of school personnel. This tendency may be due to the research design; the interviewees took knowingly part in research that dealt with their experiences as parents of pupils that are considered problematic at school. Because of this, they may 
have wanted to bring forward their own perspective which problematized the school institution rather than their children's characteristics and their poor school performances (the fact that the interviews were conducted by an unfamiliar researcher, may have contributed to this as well). This tendency could be avoided in future by conducting research in natural settings of everyday interaction (e.g., internet forums and social media) where expressing one's subjective experiences and views is easier. Another essential limitation in our study is the decision to omit fathers' voice. In future, the subjective views of fathers, siblings and children diagnosed with ADHD themselves should be considered closely in order to get a fair and full picture of home-school collaboration in the context of ADHD, or other remedial needs that at least in part derive from the requirements of school institution.

\section{References}

Ahearn, L. M. (2001). Language and agency, Annual Review of Anthropology, 30, 109-137.

Angell, M. E., Stoner, J. B., \& Shelden, D. L. (2009). Trust in Education Professionals: Perspectives of Mothers of Children With Disabilities, Remedial and Special Education, 30(3), 160-176.

Antaki, C. \& Wetherell, M. (1999). 'Show Concessions', Discourse Studies 1, 7-27.

Arnold, J. \& Clarke, D. J. (2013). What is 'Agency'? Perspectives in Science Education Research.

International Journal of Science Education. Advance online publication.

DOI:10.1080/09500693.2013.825066

Austin, H., \& Carpenter, L. (2008). Troubled, troublesome, troubling mothers; The dilemma of difference in women's personal motherhood narratives. Narrative Inquiry, 18(2), 379-393.

Carpenter, L., \& Austin, H. (2007). Silenced, silence, silent: Motherhood in the margins. Qualitative Inquiry, 13(5), 660-674.

Carpenter, L., \& Austin, H. (2008). How to be recognized enough to be included? International Journal of Inclusive Education, 12(1), 35-48. 
David, M. (1998). Involvement and investment in education: Mothers and schools, Journal for a Just and Caring Education, 4, 30-46.

Emerald, E., \& Carpenter, L. (2010). ADHD, mothers, and the politics of school recognition. In L. J. Graham (Ed.), (De)Constructing ADHD: Critical guidance for teachers and teacher educators (pp. 99-118). New York: Peter Lang.

Fairclough, N. (1992). Discourse and Social Change. Cambridge: Polity Press.

Fairclough, N. (2004). Semiotic Aspects of Social Transformation and Learning, In R. Rogers (Ed.), An Introduction to Critical Discourse Analysis in Education (pp. 225-236). New Jersey: Lawrence Erlbaum Associates.

Fairclough, N., \& Wodak, R. (1997). Critical discourse analysis. In T. van Dijk (Ed.), Discourse as social interaction (pp. 258-284). London: Sage.

Foucault, M. (1972). The archaeology of knowledge. London: Tavistock/Routledge.

Frigerio, A., Montali, L., \& Fine, M. (2013). Attention deficit/hyperactivity disorder blame game: A study on the positioning of professionals, teachers and parents. Health, 17(6) 584-604.

Gee, J. P. (2004). Discourse analysis: What makes it critical? In R. Rogers (Ed.), An introduction to critical discourse analysis in education (pp. 19-50). Mahwah NJ: Lawrence Erlbaum Associates.

Gonzalez-DeHass, A. R., Willems, P. P., \& Holbein, M. F. D. (2005). Examining the relationship between parental involvement and student motivation. Educational Psychology Review, 17, 99-123.

Graham, L. J. (2007). Out of sight, out of mind/out of mind, out of site: Schooling and Attention Deficit Hyperactivity Disorder. International Journal of Qualitative Studies in Education, 20(5), 585-602.

Greene, R. W., Beszterczey, S. K., Katzenstein, T., Park, K.., \& Goring, J. (2002). Are students with ADHD more stressful to teach?: Patterns of teacher stress in an elementary school sample. Journal of Emotional and Behavioral Disorders, 10(2), 79-89. 
Gresham, F. (2002). 'Caveat emptor: considerations before buying into the "new” medical model'. Behavioural Disorders, 27(2), 158-167.

Harborne, A., Wolpert, M., \& Clare, L. (2004). Making Sense of ADHD: A Battle for Understanding? Parents' Views of Their Children Being Diagnosed with ADHD. Clinical Child Psychology and Psychiatry, 9, 327-339.

Harré, R., \& van Langenhove, L. (1999). The dynamics of social episodes. In R. Harré, \& L. van Lagenhove (Eds.), Positioning theory (pp. 1-13). Oxford: Blackwell.

Harré, R., \& Moghaddam, F. (2003). "Introduction: The self and others in traditional psychology and in positioning theory". In R. Harré \& F. Moghaddan (Eds.), The self and others: Positioning individuals and groups in personal, political, and cultural contexts (pp. 1-11). Westport, CT: Praeger Publishers.

Harré, R., Moghaddam, F. M., Pilkerton Cairnie T., Rothbart, D., \& Sabat, S. R. (2009). Recent advances in positioning theory. Theory \& Psychology, 19(1), 5-31.

Hjörne, E., \& Säljö, R. (2004). "There is something about Julia”: Symptoms, categories, and the process of invoking attention deficit hyperactivity disorder in the swedish school: a case study. Journal of language, identity, and education, 3(1), 1-24.

Hodge, N., \& Runswick-Cole, K. (2008). Problematizing parent-professional partnership in education. Disability \& Society, 23(6), 637-647.

Hoover-Dempsey, K. V., Battiato, A. C.,Walker, J.M. T., Reed, R. P., DeJong, J. M., \& Jones, K. P. (2001). Parent involvement in homework. Educational Psychologist, 36, 195-209.

Johnston, C. \& Mash,E. (2001). Families of children with attention-deficit/hyperactivity disorder: review and recommendations for future research. Clinical Child and Family Psychology Review, 4(3), 183-207.

Karp, I. (1986). Agency and social theory: a review of Anthony Giddens. American Ethnologist. 13(1), 13137. 
Kos, J. M., Richdale, A. L., \& Hay, D. A. (2006). Children with Attention Deficit Hyperactivity Disorder and their teachers: A review of the literature. International Journal of Disability, Development and Education, 53(2), 147-160.

LeFever, G. B., Villers, M., \& Morrow, A. L. (2002). Parental perceptions of adverse educational outcomes among children diagnosed and treated for ADHD: A call for improved school/provider collaboration. Psychology in the Schools, 39(1), 63-71.

Lloyd, G. (2006). Conclusion: Supporting children in school. In G. Lloyd, J. Stead. \& D. Cohen (Eds.), Critical new perspectives on ADHD (pp. 215-228). London \& New York: Routledge.

McHoul, A., \& Rapley, M. (2005). A case of attention-deficit/hyperactivity disorder diagnosis: Sir Karl and Francis B. slug it out on the consulting room floor. Discourse \& Society, 16(3), 419-449.

O'Connor, U. (2008). Meeting in the middle? A study of parent-professional partnerships. European Journal of Special Needs Education, 23(3), 253-268.

Ohan, J. L., Cormier, N., Hepp, S. L., Visser, T. A. W., \& Strain, M. C. (2008). Does knowledge about attention-deficit/hyperactivity disorder impact teachers' reported behaviors and perceptions? School Psychology Quarterly, 23(3), 436-449.

Ohan, J. L., Visser, T. A. W., Strain, M. C., \& Allen, L. (2011). Teachers' and education students' perceptions of and reactions to children with and without the diagnostic label "ADHD", Journal of School Psychology, 49(1), 81-105.

Ohlmeier, M. D. (2008). Comorbidity of alcohol and substance dependence with attentiondeficit/hyperactivity disorder (ADHD). Alcohol and Alcoholism. International Journal of the Medical Council on Alcoholism, 43(3), 300-304.

Patrikakou, E.N., \& Weissberg, R.P. (2000). Parents' perceptions of teacher outreach and parent involvement in children's education, Journal of Prevention and Intervention in the Community, 20(1-2), 103119. 
Patton, M. (1990). Qualitative evaluation and research methods. Beverly Hills, CA: Sage.

Pelletier, J. \& Brent, J. M. (2002). Parent participation and children's school readiness: The effects of parental self-efficacy, cultural diversity and teacher strategies, International Journal of Early Childhood, 34, 45-60.

Pena, D.C. (2000). Parent involvement: Influencing factors and implications, Journal of Educational Research, 94(1), 42-54.

Potter, J. (1997). Discourse analysis as a way of analysing naturally occurring talk. In D. Silverman (Ed.), Qualitative research: Theory, method and practice (pp. 144-160). London: Sage.

Rogers, M. A., Wiener, J., Marton, I., \& Tannock, R. (2009). Parental involvement in children's learning: Comparing parents of children with and without attention-deficit/hyperactivity disorder (ADHD). Journal of School Psychology, 47(3), 167-185.

Scholtens, S., Rydell, A-M., \& Yang-Wallentin, F. (2013). ADHD symptoms, academic achievement, selfperception of academic competence and future orientation: A longitudinal study. Scandinavian Journal of Psychology, 54(3), 205-212.

Singh, I. (2002). Bad boys, good mothers and the 'miracle' of Ritalin. Science in Context, 15(4), 577-603.

Singh, I. (2004). Doing their jobs: mothering with Ritalin in a culture of mother-blame. Social Science \& Medicine 59, 1193-1205.

Smith, J. (2010). Stories from the Margin. Mothering a child with ADHD or ASD. [Review of the book Stories from the Margin. Mothering a child with ADHD or ASD, by L. Carpenter \& E. Emerald]. Health Sociology Review, 19(2), 273-275.

Soodak, L. C., \& Erwin, E. J. (2000). Valued member or tolerated participant: Parents' experiences in inclusive early childhood settings, Journal of the Association for Persons With Severe Handicaps, 25(1), 2941. 
Thomas, G., \& Loxley, A. (2007). Deconstructing special education and constructing inclusion. (2nd ed.). Maidenhead: Open University Press.

Tirado, F., \& Gálvez, A. (2007). Positioning theory and discourse analysis: Some tools for social interaction analysis. Forum: Qualitative Social Research, 8(2), Article 31.

van Dijk, T. A. (1996). Discourse, power and access. In R. C. Caldas-Coulthard \& M. Coulthard (Eds.), Text and practices: Reading in critical discourse analysis (pp. 84-104). London: Routledge and Kegan Paul.

West, J., Taylor, M., Houghton, S., \& Hudyma, S. (2005). A Comparison of teachers' and parents' knowledge and beliefs about attention-deficit/hyperactivity disorder (ADHD). School Psychology International, 26(2), 192-208.

Wetherell, M. (2001). Debates in discourse research. In M. Wetherell, S. Taylor \& S. J. Yates (Eds.), Discourse theory and practice: A reader (pp. 380-399). London: Sage. 